University at Buffalo School of Law

Digital Commons @ University at Buffalo School of Law

2014

\title{
Comparative Criminal Law
}

Luis E. Chiesa

University at Buffalo School of Law, lechiesa@buffalo.edu

Follow this and additional works at: https://digitalcommons.law.buffalo.edu/book_sections

Part of the Comparative and Foreign Law Commons, and the Criminal Law Commons

\section{Recommended Citation}

Luis E. Chiesa, Comparative Criminal Law in The Oxford Handbook of Criminal Law 1089 (Markus Dubber \& Tatjana Hörnle, eds., Oxford University Press 2014)

The Oxford Handbook of Criminal Law edited by Markus Dubber \& Tatjana Hörnle, 2014, reproduced by permission of Oxford University Press, https://global.oup.com/academic/product/the-oxford-handbook-of-criminallaw-9780199673599?cc=us\&lang=en\&

\section{IN ${ }_{\text {COPYRIGHT }}$}

This Book is brought to you for free and open access by the Faculty Scholarship at Digital Commons @ University at Buffalo School of Law. It has been accepted for inclusion in Contributions to Books by an authorized administrator of Digital Commons @ University at Buffalo School of Law. For more information, please contact lawscholar@buffalo.edu. 


\author{
COMPARATIVE CRIMINAL LAW \\ (in Markus Dubber \& Tatjana Hörnle, Oxford Handbook of Criminal Law)
}

\title{
LUIS E. CHIESA*
}

\section{INTRODUCTION}

Criminal law is a parochial discipline. Courts and scholars in the English speaking world seldom take seriously the criminal statutes, cases and scholarly writings published in the nonEnglish speaking world. The same is true the other way around. This is unfortunate. Much can be learned from comparing the way in which the world's leading legal systems approach important questions of criminal theory. This Chapter introduces the reader to comparative criminal law with the aim of demonstrating how comparative analysis can enrich both domestic and international understandings of criminal law.

The Chapter is comprised of four parts. Part I clarifies what it means to do comparative criminal law and distinguishes it from similar endeavors such as compiling criminal law. Part II explains why engaging in comparative analysis is useful to both strengthen domestic criminal law doctrines and to better understand international criminal law. Part III discusses some of the obstacles that must be overcome in order to engage in meaningful comparative analysis. Finally, Part IV engages in a comparative analysis of attempt liability and mens rea in order to illustrate how to do comparative criminal law and the benefits that might be reaped from doing so.

\section{COMPARING CRIMINAL LAW VS. COMPILING CRIMINAL LAW}

Perhaps the most obvious way of doing comparative criminal law is by compiling the criminal law doctrines of different jurisdictions. This is what Markus Dubber and Kevin Heller attempted to do with the collection of essays that they edited in the "Handbook of Comparative Criminal Law". "Each chapter of this helpful tome surveys the criminal law of a different country. The chapters are particularly useful because they are authored by leading scholars in their respective jurisdictions. This avoids the sort of mistake that an outsider is prone to make when she attempts to describe the law of a foreign country.

The problem with the useful Handbook of Comparative Criminal Law is that there is little comparative about it. The chapter on Argentine criminal law, for example, illustrates the basic principles of criminal liability invoked by courts and scholars in Argentina. The same can be said of the chapters on Spanish, American, Egyptian and Chinese criminal law. What is missing, however, is an analysis of what are the important points of contact and divergence amongst the different systems of criminal law discussed in the volume. How, for example, does the continental concept of dolus eventualis overlap with the Anglo American concept of recklessness? Why is it that the mental element (mens rea) for attempt liability in many European and Latin American countries is recklessness, while in most Anglo American countries it is purpose? Why is the analogical interpretation of criminal statutes prohibited in civil law countries but allowed in common law jurisdictions? An answer to these questions requires going

\footnotetext{
* Professor of Law and Director of the Buffalo Criminal Law Center, SUNY Buffalo Law School.

${ }^{1}$ Markus Dubber and Kevin Jon Heller (eds), The Handbook of Comparative Criminal Law (2011).
} 
beyond pointing out how different countries solve these problems. It requires comparing the different solutions.

This is not to say that compiling the criminal laws of different jurisdictions is useless. The importance of amassing materials that illustrate how foreign countries approach criminal law doctrines lies in their use as sources for doing comparative criminal law. Just as this chapter cannot be completed without making use of paragraphs, sentences and letters, there can be no comparative criminal law without employing source materials that illustrate how criminal law is approached in different jurisdictions. Ideally, comparative criminal theorists would read the seminal works published by the leading scholars of different countries and the statutory materials and case law of different jurisdictions. Unfortunately, language barriers usually make this a difficult task. As a result, works that survey the criminal laws of foreign countries quite often facilitate the task of doing comparative criminal law. Nevertheless, it is important not to confuse compiling with comparing. Comparing criminal laws is, by definition, the essence of comparative criminal law. Compiling criminal laws is useful to doing comparative criminal law, but is not synonymous with actually engaging in comparative analysis of substantive criminal law.

\section{THE USES OF COMPARATIVE CRIMINAL LAW}

\section{Comparative Criminal Law as a ToOl for Critically Assessing Domestic Criminal} LAW

It has long been argued that one of the main functions of comparative criminal law - if not its chief function - is to assist in domestic criminal law reform. ${ }^{2}$ Comparative criminal law may be useful in this regard by providing a tool with which to critically assess the domestic criminal law of the jurisdiction that is seeking to reform its laws. More specifically, an inquiry into comparative criminal law helps local actors identify instances in which their domestic criminal law may be in need of change. While this critical use of comparative criminal is most obviously relevant to legislative reform, it may also inform how the judiciary answers complex and important questions of domestic criminal law.

With regard to using comparative criminal law to fuel legislative reform, it is sensible to look to what other countries are doing in an effort to find novel solutions to old problems. Take, for example, the problem of whether and when to impose corporate criminal liability. This is an issue that is acquiring increasing importance in several Latin American and European countries. The conventionally accepted view in these countries is that punishing corporations is contrary to fundamental principles of criminal law, because corporations are not entities that are capable of behaving culpably. Given that culpability is considered to be a prerequisite for the imposition of criminal liability, these countries have historically rejected imposing criminal punishment on corporations. Nevertheless, as wrongdoing within the corporate world acquires increasing significance, these countries are starting to take seriously the idea of punishing corporations. It seems sensible that such countries consider the approaches to corporate criminal liability adopted in jurisdictions that - like the United States - have imposed such liability for over a hundred years.

\footnotetext{
${ }^{2}$ See, e.g., Thomas Weigend, 'Criminal Law and Criminal Procedure', in Jan M. Smits (ed), Elgar Encyclopedia of Comparative Law (2012).
} 
Comparative criminal law has also found its way into the judicial decision making process. In the United States, this is most obviously the case in the Supreme Court's death penalty jurisprudence. In Atkins v. Virginia, for example, the Supreme Court pointed out that "within the world community, the imposition of the death penalty for crimes committed by mentally retarded offenders is overwhelmingly disapproved". This - coupled with the fact that the vast majority of American jurisdictions prohibit the execution of mentally retarded offenders - helped support the Court's conclusion that the practice amounts to "cruel and unusual" punishment that violates the Eighth Amendment. Subsequently, in Roper v. Simmons, the high court was asked to assess the constitutionality of imposing the death penalty on a defendant who was a minor when he committed the offense. A majority of the members of the Supreme Court concluded that executing someone as punishment for a crime that was committed while under the age of 18 runs afoul the Eighth Amendment. In justifying its conclusion, the Court pointed out "that only seven countries other than the United States have executed juvenile offenders since 1990". While the Supreme Court conceded that the practices of other countries are not determinative of the meaning of the constitution of the United States, it also acknowledged that the Court frequently "refe[rs] to the laws of other countries and to international authorities as instructive for its interpretation of the Eighth Amendment's prohibition of 'cruel and unusual punishments". 5

Finally, comparative criminal law is also useful as a tool for enriching scholarly enterprises. It can be used in the classroom to help students better understand the strengths and weaknesses of the domestic system of criminal law that they are learning about. Take, for example, the issue of whether criminal liability should be imposed for failing to rescue a stranger in need of help in circumstances in which doing so would not be costly or dangerous. As every American law student learns early in their basic substantive criminal law course, such omissions typically go unpunished in the United States. This might seem unremarkable to many American students, especially if they have already learned that such failures to rescue do not generally give rise to tort liability either. While perhaps some students will notice the obvious disconnect between law and morality in this context, most will likely conclude that this is just the standard legal answer to this question. Such passive acceptance of the American reticence to punish omissions to aid can be challenged by venturing into the realm comparative criminal law. Students are often surprised when they learn that punishing failures to rescue is the norm in most European and Latin American countries. This, in turn, allows them to see that there need not be a disconnect between law and morality in this area and that the American approach to punishing failures to aid is by no means the universal way of thinking about this issue. The hope is that such comparative insights may help students broaden their perspectives and call into question entrenched domestic criminal law doctrines.

\section{Comparative Criminal LaW as a Source of International CRiminal LaW}

International criminal law has gained increasing importance in recent years, especially after the adoption of the Rome Statute creating the International Criminal Court (ICC). Before the Rome Statute was adopted in 2002, general doctrines of international criminal law were not summarized in a single treaty and therefore slowly emerged as a result of customary law and the

\footnotetext{
${ }^{3} 536$ U.S. 304 (2002).

${ }^{4} 543$ U.S. $551(2005)$.

${ }^{5}$ Ibid.
} 
judgments of certain international courts, such as the Nuremberg Tribunal and the International Criminal Tribunals for Rwanda (ICTR) and the Former Yugoslavia (ICTY). As a result, the adoption of rules of international criminal law to govern issues such as complicity, mens rea, attempt liability and general justification and excuse defenses was heavily influenced by the way in which these issues were addressed in domestic systems of criminal law.

It should come as no surprise, then, that an inquest into comparative criminal law proved of great importance in ascertaining the content and scope of general doctrines of international criminal law. International tribunals continuously make reference to the domestic criminal laws of different jurisdictions in order to fill gaps in international criminal law doctrines in accordance with the "general principles of law recognized by civilized nations". 6

A particularly rich example of this is the ICTY's judgment in Prosecutor $v$. Drazen Erdemovic. $^{7}$ The defendant in Erdemovic claimed that his killing of dozens of innocent civilians should be excused pursuant to the defense of duress. The novel legal issue presented by the case was whether duress could be invoked as a defense to a crime against humanity. A majority of the judges of the Court ruled that duress cannot fully excuse crimes of such magnitude. An analysis of comparative approaches to this question proved determinative to the Court's decision. The Court explained its reliance on comparative criminal law in this manner:

In order to arrive at a general principle relating to duress, we have undertaken a limited survey of the treatment of duress in the world's legal systems. This survey is necessarily modest in its undertaking and is not a thorough comparative analysis. Its purpose is to derive, to the extent possible, a "general principle of law" as a source of international law. ${ }^{8}$

After surveying the law of twenty eight countries regarding this issue, the Court pointed out that most civil law jurisdictions seem to allow duress to be pleaded as a defense to the killing of innocent persons, whereas most common law jurisdictions do not. Nevertheless, it also asserted that the vast majority of common and civil law countries allow duress to be raised as a mitigating factor. Ultimately, the Court decided against allowing duress to fully excuse a crime against humanity. The ICTY partially justified this conclusion by pointing out that there was no international consensus regarding whether duress should fully excuse killings of innocent people. The Court, however, concluded that in light of the overwhelming consensus in favor of allowing duress to be considered as a ground for reducing punishment, duress ought to be admissible at the sentencing stage to mitigate punishment.

Regardless of the merits of the holding in Erdemovic, ${ }^{9}$ the case highlights the special role that comparative criminal law plays in international criminal law adjudication. This role is even more obvious after the creation of the ICC, given that pursuant to the Rome Statute, the Court

\footnotetext{
${ }^{6}$ This is one of the conventionally accepted sources of international law, as recognized in Art. 38(1)(c) of the International Court of Justice Statute.

${ }^{7}$ ICTY judgment of 7 of October, 1997.

${ }^{8}$ Ibid., at paragraph 58 .

${ }^{9}$ Many scholars have found the analysis in Erdemovic wanting. See, e.g., my 'Duress, Demanding Heroism and Proportionality: The Erdemovic Case and Beyond', (2008) 41 Vanderbilt Journal of Transnational Law 741.
} 
must apply "general principles of law derived...from national laws of legal systems of the world". 10

\section{Challenges of COMPARAtive Criminal LaW}

\section{THE LANGUAGE BARRIER}

The most obvious challenge to engaging in comparative criminal law analysis is overcoming language barriers. While this is a problem that plagues comparative law in general, it is particularly acute in the case of comparative criminal law. The dearth of English translations of foreign criminal law cases, statutes and scholarly writings is remarkable, especially when German, Italian and Spanish criminal theory have achieved a very high level of sophistication. Similarly, the lack of translations of textbooks, articles, statutory materials and case law originally published in English hinders the propagation of Anglo-American criminal theory to jurisdictions steeped in the European Continental legal tradition.

Perhaps because of this, it happens quite often that scholars on either side of the Atlantic believe that they have come up with a novel solution to a criminal law problem that unbeknownst to them - has already been proposed by scholars hailing from a different legal tradition. Two cases immediately come to mind. Several decades ago, American criminal theorists Paul Robinson and George Fletcher famously debated whether and how much an "unknowingly justified" actor should be punished. An actor is unknowingly justified when he is unaware that his conduct prevents a harm that is greater than the harm caused by his act. Suppose that a person kills another out of spite without knowing that the person he killed was about to use deadly force against him. Such a killing is objectively justified pursuant to self-defense. However, should the actor be able to successfully plead self-defense when he was unaware that the killing was necessary to avert an unlawful attack? Paul Robinson forcefully argued that justifications are objective and - therefore - harms caused by unknowingly justified actors ought to be justified even if they are acting for bad reasons. ${ }^{11}$ Nevertheless, Robinson argued that attempt liability could be imposed, for the unknowingly justified actor tried to cause a net social harm but failed. ${ }^{12}$ In contrast, George Fletcher argued that justifications must be earned by the actor. Consequently, Fletcher contended that unknowingly justified actors should be punished for a completed offense, since they lack subjective awareness of the justifying factors, which is essential to establish that their conduct is motivated by the right reasons. ${ }^{13}$

What is particularly interesting about this is that although Fletcher is widely considered in America to be heavily influenced by German criminal law theory, Robinson's position regarding the unknowingly justified actor was defended by many - if not most - German criminal theorists well before the famous Robinson-Fletcher debate. That is, most German scholars argue that unknowingly justified actors should be punished for an attempt rather than for

\footnotetext{
${ }^{10}$ This mandate applies in circumstances in which the governing principles of law cannot be surmised from the Rome Statute itself or other international legal materials. See Art. 21(1)(c) of the Rome Statute.

${ }^{11}$ Paul H. Robinson, 'A Theory of Justification: Societal Harm as a Prerequisite for Criminal Liability', (1975) 23 U.C.L.A. L.R. 266.

${ }^{12}$ Ibid.

${ }^{13}$ George P. Fletcher, 'The Right Deed for the Wrong Reason: A Reply to Mr. Robinson', (1975) 23 U.C.L.A. L.R. 293.
} 
a consummated crime. ${ }^{14}$ And they had done so many years prior to the famous RobinsonFletcher exchange. As a result, in the big scheme of things, Robinson's position was not as novel as many - including Fletcher - believed it to be. This debate would have surely benefited from the reasoned analysis of civil law scholars who had for a long time argued that attempt liability ought to be imposed on unknowingly justified actors. Unfortunately, the lack of English translations of criminal law writings from European Continental scholars made it nearly impossible for American scholars to note that this debate was not as original as it seemed.

For similar reasons, civil law scholars have failed to appreciate that some of their contributions to criminal law theory may not be as groundbreaking as they believe. Take, for example, the theory of "objective imputation" that German scholars concocted to deal with causation problems in borderline cases. According to the most modern version of the theory, an actor ought to be held accountable for resulting harm only if two conditions obtain. First, the actor's conduct must create an unreasonable risk of harm. Second, the resulting harm must be the consequence of the particular risk created by the actor's conduct rather than the product of a different risk. ${ }^{15}$

The oft-cited facts of People vs. Acosta ${ }^{16}$ may be used to illustrate the theory of "objective imputation". The police were alerted that the defendant in Acosta stole a car. A car chase ensued. Two police helicopters were dispatched to follow the movements of the defendant. Unfortunately, the helicopters crashed unto one another. Both pilots died. The issue was whether the defendant should be held accountable for the deaths of the pilots. According to the theory of "objective imputation", the answer is straightforward. The defendant should not be held liable because the ex ante risk created by the defendant was possible harm to those using the roads, whether they be pedestrians or other drivers. However, his conduct did not create an ex ante risk of harm to those navigating the skies. Therefore, the resulting harm (death of helicopter pilots) cannot be fairly attributed to the defendant.

Surely this conclusion will strike many Anglo-American readers as normatively appealing. It will not strike them, however, as novel. The notion that fair attribution of harms should be the product of a comparison between the ex ante risks created by the defendant and the risk that actually ends up producing the harm is at least as old as the venerable Palsgraf v. Long Island Railroad case. ${ }^{17}$ It was there that Judge Cardozo famously stated that "the risk reasonably to be perceived defines the duty to be obeyed, and risk imports relation; it is risk to another or to others within the range of apprehension". 18 In doing so, he captured the essence of the modern continental doctrine of objective imputation more than forty years before the German scholar Claus Roxin was credited with doing so in civil law jurisdictions.

In sum, the comparison of risks that is so essential to most modern version of the theory of objective imputation has been a part of the Anglo-American discourse of causation in the law for the better part of one hundred years. Only that it was not - and still is not - called objective imputation. It is called proximate or legal causation. But it is essentially the same thing.

\footnotetext{
${ }^{14}$ See, e.g., Günther Jakobs, Derecho Penal: Parte General (trans. Cuello Contreras, et al.) (1995), 434.

${ }^{15}$ See, generally, Diego-Manuel Luzón Peña, Lecciones de Derecho Penal: Parte General (2nd ed., 2012), 211.

${ }^{16} 284$ Cal. Rptr. 117 (1991).

${ }^{17}$ Palsgraf v. Long Island Railroad, 248 N.Y. 339 (1928).

${ }^{18}$ Ibid., at 344.
} 
Unfortunately, it is difficult to tell that this is the case. If an online search engine is used to look for the terms "objective imputation", no Anglo-American case or scholarly writing will show up. It might then be tempting to conclude that there is no analogue to the continental theory of "objective imputation" in Anglo-American criminal law. This conclusion, however, would be wrong. This is a classic illustration of how the scholar interested in gaining comparative insight could easily get lost in translation. While no Anglo-American court or scholar will use the terms "objective imputation", many will reference legal or proximate causation. It would thus be quite useful for scholars to know that the Anglo-American proximate causation inquiry is very similar to the European Continental "objective imputation" inquiry. Such knowledge would save them the time that would be invested looking in vain for objective imputation in Anglo-American cases and scholarly writings. It would also allow them to appreciate that the theory of objective imputation is not so groundbreaking after all, for a similar idea germinated in American tort law almost half a century before the modern risk based theory blossomed in Germany.

The lesson to be learned from this is not that an inquest into comparative criminal law reveals that the Robinson-Fletcher debate is less valuable than many American scholars think it is or that the theory of objective imputation is less novel than many European Continental scholars believe. What these comparative insights highlight, however, is that we should proceed with a dose of scholarly humility when tackling issues of criminal law theory, for what we take to be a venture into uncharted theoretical territory may very well amount to traversing through well trodden ground if one could only look at the problem from a comparative perspective.

The other lesson to be learned from this brief comparative foray into the problems of the unknowingly justified actor and the theory of objective imputation is that the scarcity of translations of seminal criminal law works makes it very difficult to engage in meaningful comparative analysis unless one is fortunate enough to be able to read the works without translation. Unfortunately, few people are able to do so. This highlights the importance of works like Dubber and Heller's Handbook of Comparative Criminal Law. Although the contributions compiled in the Handbook do not truly engage in comparative analysis, each chapter usefully summarizes the law of a particular country. This is a wonderful source for engaging in comparative analysis. Nevertheless, in order for comparative criminal law to take real flight, it will be necessary to remedy the awful lack of translated criminal law source materials. Until this happens, robust comparative inquiry is destined to remain the province of the few who are able to overcome the challenges posed by the language barrier.

\section{The Legal Barrier - Common Law vs. Civil Law Approaches to Legal Reasoning}

Another challenge for those who are interested in doing comparative criminal law is understanding how the legal systems being compared differ from each other in ways that may influence how each respective legal tradition approaches law in general and the criminal law in particular. While there are many ways in which common law and civil law systems vary, one particularly important difference is the manner in which lawyers in each jurisdiction reason their way through a legal problem.

In general, common law lawyers approach criminal law (and other areas of law) inductively. That is, they start with a case (or group of cases) that they are trying to resolve in a fair way. They decide the case in a way that seems appropriate. Similar cases are subsequently decided in similar ways. Eventually, a principle that explains why these cases are decided in 
similar fashion arises as a result of inductive reasoning. Common law lawyers thus move from specific cases to broad principles. But the principles come into being because they adequately account for the correct resolution of the individual cases. If cases arise in the future which cannot be resolved fairly by applying the principle, common law lawyers are quite amenable to revising or abandoning the principle if doing so is the only way of resolving a concrete case (or a group of cases) in an appropriate manner. Take, for example, the case of whether the torture of a suspect can ever be justified pursuant to the lesser evils (necessity) defense. For decades the position in the United States seemed to be that torture could never be justified. Nevertheless, the American experience with terrorism during and after the bombing of the World Trade Center has led to crafting so-called ticking time bomb scenarios whose proper resolution calls into question the long-standing principle that torture can never be justified. Faced with such ticking time bomb scenarios, some now argue that torturing a person may be allowed if it is the only way to acquire information that will help prevent a catastrophe. This, in turn, has led a group of scholars and practitioners to call into question the long-standing principle that torture should never be justified. Others oppose this move. It remains to be seen whether this discussion - with its underlying focus on ticking time bomb cases - will lead to a revision of the absolute principle against torture.

In contrast, civil law lawyers typically reason their way through a legal problem in deductive fashion. That is, they begin their analysis of a case with a seemingly applicable principle that is generally accepted as both sound and binding. They then apply the principle to the case at hand to arrive at a solution. Civil law lawyers therefore typically move from broad generally accepted principles to the specific resolution of concrete cases. As a result, unlike in common law jurisdictions, the principles are not justified because they provide intuitive outcomes in particular cases. Rather, the principles are justified because they are viewed as independently sound or binding regardless of whether they produce intuitive or counterintuitive solutions to particular cases. The principle is viewed as authoritative or sound if it can be derived from even broader legal, political or moral commitments. The torture example is once again illustrative. The principle that torture may never be justified pursuant to lesser evils (or any other justification defense) is deeply engrained in civil law jurisdictions. It is accepted as both a sound and binding principle of law that derives its legitimacy from a host of even broader legal and political commitments, including international conventions against torture. This principle compels the conclusion that torturing cannot be legally justified and the conclusion holds regardless of whether abiding by it produces unappealing or counterintuitive solutions in ticking time bomb scenarios. Principles are thus much more immune to revision and abandonment in civil law jurisdictions than they are in common law countries. This is primarily due to the fact that - in contrast with what occurs in common law jurisdictions - principles in European Continental jurisdictions are not derived inductively from the resolution of specific cases, but rather deductively from even broader political or moral commitments. Therefore, the fact that applying a given principle (torture is always wrong) may produce counterintuitive results in a given case (ticking time bomb scenarios) is not seen in civil law jurisdictions as a decisive or even a particularly strong reason for modifying the principle.

In sum, the way in which lawyers reason their way through legal problems in common and civil law jurisdictions varies considerably. This influences how much weight each legal tradition affords to certain principles of criminal law. Failing to understand this may lead to misapprehending why Anglo-American and European Continental jurisdictions are more or less 
prone to modifying long held principles of criminal law when applications of such principles produces counterintuitive results in certain cases.

\section{The CUltural/HistoricAl BARRIER}

Engaging in comparative criminal law analysis is further complicated by historical and cultural contingencies that significantly contribute to shaping the way in which criminal laws have evolved in the world's different legal systems. Many important features of Anglo-American criminal law, for example, cannot be fully grasped without first understanding the historical role of the judge in common law countries. By the same token, several significant features of civil law approaches to criminal law can only be fully explained by the horrifying events that the people of many European and Latin American states experienced while their countries were governed by cruel authoritarian regimes. A failure to take into account how historical contingencies such as these shape the legal culture of different countries quite often leads to misapprehending the legal system of a particular jurisdiction.

Take, for example, the divergent ways in which common law and civil law jurisdictions approach the so-called "legality principle". This principle is at least nominally followed in both Anglo-American and European Continental jurisdictions. Nevertheless, the content and scope of the legality principle in the world's two leading legal systems varies considerably. In civil law countries, for example, the legality principle prohibits using analogy to interpret criminal statutes in a way that is prejudicial to the defendant. ${ }^{19}$ There is no such prohibition in common law jurisdictions. ${ }^{20}$ What explains the difference? The explanation lies in the role that the judge has historically played in common law and civil law jurisdictions.

As is well known, the law making power of courts in common law countries was so far reaching that at one point most offenses were "common law crimes" of judicial creation. While most criminal law in Anglo-American jurisdictions is now statutory and common law crimes have by and large been abolished, judges in common law countries still retain much more power than their civil law counterparts. In contrast, judicially created crimes have historically been rejected civil law jurisdictions, where all criminal law is statutory law. The role of the judge in these countries is therefore limited to interpreting already existing law rather than creating new law. This is why construing criminal statutes analogically is prohibited in European Continental jurisdictions. A court that expands a statute beyond the conventionally accepted meaning of the terms to encompass cases that can - by a process of analogical reasoning - be likened to the cases that actually fall within the clear scope of the rule is tantamount to exercising lawmaking powers. Wielding such judicial power is viewed with suspicion, for in civil law countries lawmaking authority has historically been reserved for the legislative branch of government. This stands in stark contrast with the role typically afforded to the judiciary in common law countries. Given that Anglo-American courts have traditionally wielded lawmaking authority, it does not seem

\footnotetext{
${ }^{19}$ See, e.g., Santiago Mir Puig, Derecho Penal: Parte General (7th ed., 2004), 125.

${ }^{20}$ In America, the "rule of lenity" is often invoked to resolve ambiguity in criminal statutes in favor of defendants. The rule, however, is not constitutionally mandated. It is also rejected by Section 1.02(3) of the Model Penal Code. In contrast, the prohibition of analogy in most civil law jurisdictions is constitutionally based. The American Constitution, on the other hand, does not bar the analogical interpretation of statutes. At most, it prohibits retroactively expanding the scope of criminal statutes in a way that is unforeseeable. See Bouie v. City of Columbia, 378 U.S. 347 (1964). Bouie and its progeny do not seem to bar, however, unforeseeable judicial expansions of statutes if they are only applied prospectively.
} 
objectionable for the judiciary to broadly construe criminal statutes by engaging in a process of analogical reasoning.

This remains the case even after the abolition of common law crimes, since the elimination of such offenses merely highlights that the branch of government that is primarily responsible for creating crimes is the legislature. In spite of the primacy now afforded to the legislative branch in criminal law matters, courts in common law countries continue to exercise residual lawmaking power in the interstices of criminal law. Thus, when criminal laws are drafted by the legislature in an excessively vague manner, common law courts often exercise their residual lawmaking powers to infuse the initially vague legal text with much needed precision. ${ }^{21}$ Exercising this kind of judicial power would be illegitimate in civil law jurisdictions, where the principle of legality requires that the legislature draft criminal statutes with sufficient precision from the outset. If the legislative branch fails to do so, the judiciary is barred from saving the statute by infusing it with the required specificity. ${ }^{22}$ Allowing courts to do so would once again - confer them lawmaking authority that is incompatible with the historical role of the judiciary in civil law jurisdictions.

This succinct comparative analysis of the principle of legality reveals several nuances that would easily be lost if one fails to take into account the historical idiosyncrasies of common and civil law systems. For obvious reasons, the civil law tradition is much more committed to the idea that the legislature is the sole source of legitimate lawmaking authority. In contrast, the common law tradition is much more amenable to sharing lawmaking authority between the judiciary and the legislature (and even the executive). As a result of this important difference, the world's two leading legal traditions approach the principle of legality in divergent ways. In continental jurisdictions, the principle of legality prohibits expanding the scope of criminal statutes by engaging in a process of analogical reasoning. No such bar exists in common law jurisdictions. Also, civil law countries prohibit courts from infusing vaguely drafted statutes with the precision that is needed to provide fair warning to citizens as to the conduct prohibited by the law. The principle of legality in common law countries does not prohibit doing so.

These important differences between common law and civil law conceptions of the principle of legality remain largely undertheorized, probably due to the fact that it is incorrectly assumed that the principle of legality has the same scope in both Anglo-American and European Continental jurisdictions. This assumption is easily debunked once attention is paid to the link between the principle of legality and the proper allocation of lawmaking power between the different branches of government. If different legal traditions allocate lawmaking authority in different ways - as the civil law and common law traditions do - then it should come as no surprise that the principle of legality is construed differently in Anglo-American countries that are committed to an active judiciary than in European Continental countries that are committed to a more passive judicial branch.

An even more striking example of the importance of taking into account historical experiences when engaging in comparative analysis of criminal laws is the different ways in which common law and civil law jurisdictions approach the necessity (choice of evils) defense. The necessity defense justifies engaging in conduct that satisfies the elements of an offense when

${ }^{21}$ This practice was approved by the United States Supreme Court in Rose v. Locke, 423 U.S. 48 (1975).
${ }^{22}$ See, e.g., Luzón Peña (n 7), 59. 
doing so averts an evil that is greater than the one caused. The balancing of evils is usually straightforward. A person may, for example, justifiably break a window of a car in order to save a child who is suffocating inside the vehicle. Although such conduct satisfies the elements of the offense of criminal damages, the evil averted (death of the child) clearly outweighs the evil inflicted (damage to the vehicle's window). In some cases, however, the balance of evils is not clear cut. This is especially the case when the harm inflicted is the death of an innocent person. It is unclear, for example, whether killing an innocent person should be justified as a lesser evil because it prevents the death of two innocent people.

Interestingly, common law and civil law jurisdictions have taken different approaches to solving the balancing question in these cases, especially in the last several decades. During the second half of the twentieth century, the American approach to this question has shifted decidedly in favor of allowing - at least in principle - an actor to claim that the killing of an innocent human being is justifiable because it was necessary to avert the deaths of even more people. While there are no recent American cases directly on point, the drafters of the influential Model Penal Code certainly believed this to be the correct interpretation of the Code's choice of evils provision. ${ }^{23}$ Support in the scholarly literature in favor of the proposition that taking innocent life is justified if it saves more lives is also growing in Anglo-American scholarly literature. ${ }^{24}$ A similar principle also seems to underlie a relatively recent judgment of the Court of Appeal of England and Wales in which the court authorized severing conjoined twins in a way that would kill one of the twins in order to save the other. ${ }^{25}$

Scholars in civil law jurisdictions have, on the other hand, continuously rejected justifying conduct that sacrifices innocent human life even when doing so is necessary to save more lives than the ones sacrificed. Their position is summed up by Andenaes, a famous Norweigan criminal theorist, in the following manner: "[e]ven though many lives could be saved by the sacrifice of one, this would hardly be justifiable...[for it] would conflict with the general attitude toward the inviolability of human life to interfere in this way with the course of events." 26 This approach is so deeply ingrained in the legal culture of civil law countries, that it has been expressly incorporated into some domestic criminal codes. Thus, for example, the choice of evils defense as defined in the Puerto Rican Penal Code justifies conduct only when the "evil caused is considerably inferior to the one averted and it does not entail causing either death or grave and permanent harm to the physical integrity of a person". ${ }^{27}$ This viewpoint was also at the core of the relatively recent decision of the German Constitutional Court striking down a statute that authorized downing a commercial airplane headed towards a heavily populated area. ${ }^{28}$ The statute was struck down in spite of the German government's argument that shooting down planes in those circumstances ought to be justified because it saves more lives than the ones sacrificed. According to the German high court, the problem with this is that it is incompatible with the basic right to dignity and life recognized in the German Basic Law

\footnotetext{
${ }^{23}$ Model Penal Code Section 3.02, cmt. 3, at 14-15 (Official Draft and Revised Comments 1980).

${ }^{24}$ See, e.g., Wayne R. LaFave, Substantive Criminal Law Section 10.1 (d)(2) (2d ed. 2003). Joshua Dressler, Understanding Criminal Law (2012), Section 22.04.

${ }^{25}$ Re A (children) (conjoined twins: surgical separation), [2005] 4 All ER Ca 961.

${ }^{26}$ Johannes Andenaes, The General Part of the Criminal Law of Norway (trans. Thomas Ogle) (1965), 169.

${ }^{27}$ Art. 26 of the Puerto Rico Penal Code of 2012.

${ }^{28} 1$ BvR 357/05 (2006).
} 
because it treats the lives of the plane's passengers as mere objects or instruments that can be used to bring about good consequences.

What explains the widely divergent civil law and common law views regarding the justifiability of sacrificing innocent life in order to maximize the number of lives saved? While there surely are several explanations for this, there is a historical reason that cannot be ignored when trying to make sense of this divergence. During the twentieth century, many citizens of European and Latin American countries suffered through the harrowing experience of being governed by authoritarian leaders who committed unimaginable atrocities upon large swaths of the civilian population. The atrocities were quite widespread in scope. In many countries including Guatemala and Germany - members of certain groups were systematically killed. In other countries - like Argentina, Chile and Spain - tens of thousands of citizens disappeared during the course of bloody military dictatorships.

The historical contrast with most Anglo-American countries is stark. Although some of the leading common law countries fought bloody wars during the course of the twentieth century, few had to endure the commission of atrocities that are similar in scale to the ones experienced by citizens of many European and Latin American countries. Few had to face governmental abuses in which marginalized sectors of the population were slaughtered or kidnapped in the name of the common good of the country. These disparate experiences account - at least in part - for the skepticism with which European and Latin American countries view the claim that it is sometimes worthwhile to sacrifice the lives of few for the benefits of the many. While the theoretical plausibility of this position is evident, the harrowing history that citizens of many civil law countries had to bear makes the population of these jurisdictions shudder at the thought of allowing people to claim that killing innocents may sometimes be beneficial for the aggregate welfare of the community.

It is not, of course, that citizens, scholars and legal actors in civil law countries fail to grasp the cogent consequentialist arguments that militate in favor of justifying the killing of some innocent persons in order to save many more. It is that - notwithstanding how persuasive such arguments may seem when examined in the abstract - history has taught them that whatever benefit may be reaped by justifying actors who take innocent life in order prevent even greater harm is simply outweighed by the potential for abuse inherent in authorizing such awesome power. This is why consequentialist justifications of the sort that appeal to American scholars and the drafters of the Model Penal Code ring hollow to many scholars in Europe and Latin America. When what people are capable of doing in the name of the law and the common good when motivated perverse ideals is personally witnessed, it is quite natural to think twice before expanding the scope of claims that might be invoked by the government (and others) to justify taking innocent life. Those who lack firsthand experience of how insufferable "man's inhumanity to man" can be simply cannot see this as clearly as those who do.

It is very difficult to assess the relative merits of the divergent solutions offered to the problem of whether to justify some killings of innocent civilians without accounting for the important historical and cultural differences between common law and civil law countries mentioned here. Common law scholars approach the question of whether necessity ought to sometimes justify killings of innocent people from a mostly philosophical perspective. In contrast, civil law scholars tackle the question mostly by drawing lessons from their historical experiences, even if the lessons cannot be easily squared with consequentialist philosophy. It is 
easy to lose sight of these nuances if the issue is approached without giving proper weight to the historical and cultural factors that shape the content and scope of legal rules in the systems that are being compared.

\section{DOING COMPARATIVE CRIMINAL LAW - TwO EXAMPLES}

This section actually engages in comparative analysis of certain criminal law doctrines. The purpose of doing so is to provide concrete examples that illustrate how to do comparative criminal law. An additional goal is to demonstrate how engaging in comparative analysis can lead to a better understanding of how and why domestic criminal law takes its current shape. The section begins by comparing common law and civil law approaches to attempt liability. It then turns to exploring mens rea from a comparative perspective, with specific emphasis on the differences between the continental mental state of dolus eventualis and the Anglo-American mental state of recklessness.

\section{CRiminal ATtEMPTS}

Failed attempts to consummate an offense are punished in both civil and common law jurisdictions. Nevertheless, there are significant differences in how the world's two leading legal systems approach both the objective (actus reus) and subjective elements (mens rea) of punishable attempts. Before discussing the specific differences between both systems in this context and the reasons that might explain such differences, it is useful to briefly outline the most important issues that must be addressed by any jurisdiction that is interested in developing a coherent theory for imposing attempt liability.

Most of the specific offenses listed in the special part of criminal codes criminalize successfully engaging in certain conduct or causing a particular result. Thus, the offense of rape prohibits engaging in non-consensual sexual intercourse. The offense of homicide criminalizes causing the death of a human being. In both cases, the prohibited act is effectively engaging in either the prohibited conduct (engaging in non-consensual sexual intercourse in the case of rape) or successfully bringing about the proscribed harm (death in the case of homicide). The special part of criminal codes usually prescribes punishment only for those who complete the conduct described in the definition of the offense. The consequence of this is that those who try but fail to engage in the conduct proscribed by the offense do not, strictly speaking, perform an act that is prohibited by the law defining the criminal offense. Nevertheless, there are powerful consequentialist and retributive reasons for punishing those who try to engage in criminal conduct but (fortunately) do not succeed. That is, we have good reasons to punish those who try but fail to kill and those who try but fail to rape. The doctrine of attempt liability was created to address this gap in the law. Pursuant to this general doctrine, criminal liability attaches whenever someone tries to commit an offense but fails to successfully consummate it. The world's leading systems of criminal law are in general agreement up to this point. The similarities, however, end here.

The first point of divergence has to do with determining the exact point in time during which conduct crosses the threshold from being a mere act of preparation that generally goes unpunished to being an act of execution of the criminal offense that is typically punished as an attempt. This is the problem inherent in figuring out what the objective element (actus reus) of attempt offenses should be. It is a particularly thorny problem, given that often many events take 
place between the time during which the actor first contemplates the commission of the offense and the moment in which the offense is completed. Many things happen, for example, between the time that the actor thinks about poisoning the victim and the moment in which the actor actually poisons and kills the victim. When exactly did the actor's conduct become a punishable attempt? When he contemplated killing the victim? When he called a friend to ask for help? When he browsed the web looking for a poison with which to kill the victim? When he bought the poison? When he drove to the victim's home? When he entered the home? When he poisoned the coffee?

Until the second half of the twentieth century, both common law and civil law jurisdictions distinguished unpunished acts of preparation from punishable acts of execution in very similar ways. There was generalized consensus in Anglo-American and European Continental literature and case law that attempts to commit offenses should only be punished if they come dangerously close to completion. Anglo-American courts and commentators suggested that the act must be "dangerously proximate" to completion ${ }^{29}$ or that the actor must engage in the "last act" prior to consummation of the offense. ${ }^{30}$ Similarly, continental scholars argued that only acts "immediately prior to engaging in conduct that satisfies the elements of an offense" 31 or that "place the victim in danger" 32 should be punished as attempts. Regardless of the specific standard invoked, however, attempts were typically punished only when the actor came very close to consummating the offense. Applying these tests to the facts in the abovementioned example, the actor would probably not be punished for an attempt until at least when he enters the victim's home. The acts of browsing the web to look for poison, buying the poison and driving up to the victim's home would very likely remain unpunished.

This generalized consensus started eroding after the publication in the United States of the Model Penal Code in 1962. According to Section 5.01 of the Code, an actor's conduct is punished as an attempt if it amounts to a "substantial step" in furtherance of the eventual commission of the offense. The acts that count as a substantial step are quite broad and are often far removed both in time and space from the actual consummation of the crime. Examples of acts that count as substantial steps include buying a weapon for use in a murder, reconnoitering the place that will be robbed and driving around town looking for the person that will be mugged. None of these acts would likely be punished as an attempt in civil law jurisdictions. They would also not seem to amount to criminal attempts in common law countries prior to the publication of the Model Penal Code.

The substantial step test quite often leads to imposing attempt liability for conduct that is not close or proximate to the completion of the crime and that has in no way endangered the potential victim of the offense. Also, unlike the tests that draw the line between preparation and execution closer to consummation, the substantial step test focus more on the substantiality of the acts that were done by the actor rather than on the importance of the acts that remain to be done. The influence of the Model Penal Code's substantial step test has been considerable. Over half of the states in America follow a version of this test, as well as close to two thirds of the United States Circuit Courts of Appeals.

\footnotetext{
${ }^{29}$ See, e.g., People v. Rizzo, 246 N.Y. 334 (1927).

${ }^{30}$ See, e.g. $R$ v. Eagleton, 6 Cox C.C. 559 (Ct. Crim. Law 1855).

${ }^{31}$ See, e.g., Hans Welzel, Derecho Penal Alemán (trans. Bustos, et al.) (11 ${ }^{\text {th }}$ ed., 1997), 224.

${ }^{32}$ See, e.g., Mir Puig (n 19), 347.
} 
The scope of attempt liability has not been broadened in similar fashion in continental jurisdictions. This recent divergence in the punishment of attempts calls for an explanation. Why were the common law and civil law approaches to the actus reus of attempt liability so similar for so long and why have they now started diverging?

A possible explanation for this is that, during the course of the twentieth century, common law countries began to focus more on the actor's subjective culpability and less on harm causation as a proxy for when punishment is warranted. This was especially the case with the influential Model Penal Code, which was more concerned with identifying dangerous individuals than with redressing the harm caused by the offense. ${ }^{33}$ This trend was not as pronounced in civil law countries. The vast majority of continental scholars have advocated during the last several decades for a criminal law that is designed primarily to redress harm caused to legally protected interests. ${ }^{34}$ In words frequently echoed in continental scholarly literature, the criminal law should be concerned with acts rather than actors. ${ }^{35}$ As a result, the focus of attempt liability in civil law countries continues to be whether there has been an act that endangers a legally protected interest rather than whether the actor has revealed that he is dangerous and in need of correction. In contrast, the focus in many common law jurisdictions especially the United States - shifted to assessing the subjective culpability and dangerousness of the actor. This has led to casting a wider net of attempt liability with the hope of identifying and neutralizing dangerous actors way before they come close to causing harm.

There are also differences in the common law and civil law approaches to the subjective element (mens rea) of attempt liability. In Anglo-America, attempt liability is usually imposed only if the actor had the purpose of bringing about the harm prohibited by law. Liability for attempts thus presupposes that the actor's conscious objective be causing the state of affairs that is proscribed by the statute. On the other hand, it is increasingly the case in continental jurisdictions that an actor may be held liable for an attempt as long as he acts recklessly with regard to the possibility of harm. ${ }^{36}$ Things were not always this way. Until late in the twentieth century, there was much debate in some continental jurisdictions regarding whether the subjective element of attempts should be recklessness or purpose. ${ }^{37}$

In this context, the civil law approach generates broader attempt liability than the common law approach. While in continental jurisdictions attempt liability may be imposed when the defendant acts with purpose, knowledge or recklessness, in Anglo-American jurisdictions liability may only be imposed when the defendant acts purposely. This is particularly interesting because the continental rules governing the actus reus of attempts are significantly restrictive when compared with the more permissive Anglo-American rules, especially the ones modeled on the substantial step test. The end result is that there has been an expansion in the scope of attempt liability in both continental and common law countries. Only that the expansion of attempt liability in common law jurisdictions is mostly the product of watering down the objective

\footnotetext{
${ }^{33}$ See, generally, Markus Dubber, 'Penal Panopticon: The Idea of a Modern Model Penal Code', (2000) 4 Buffalo Criminal L.R. 53 (arguing that the MPC was concerned mostly with identifying, deterring and/or correcting dangerous offenders).

${ }^{34}$ See, e.g., Luzón Peña (n 15), 25.

${ }^{35}$ Ibid., 24.

${ }^{36}$ See, e.g., Jakobs (n 14).

${ }^{37}$ This issue was hotly debated in Argentina, for example. See, e.g., Eugenio Raúl Zaffaroni, Alejandro Alagia and Alejandro Slokar, Derecho Penal: Parte General (2002), 822-824.
} 
element of attempts, while the expansion in civil law jurisdictions is primarily the result of watering down the subjective element of attempts.

But why have common and civil law jurisdictions expanded attempt liability by focusing on different elements? Once again, it seems dependent on whether attempt liability is viewed as a tool for identifying dangerous actors in need of correction or if attempts are conceived as a way of punishing those who have endangered someone. As a mechanism for identifying dangerous individuals, attempt liability should focus mostly on the actor's subjective culpability. Whether a person was actually endangered by the defendant's conduct is only mildly relevant to assessing the defendant's dangerousness. Ultimately what matters is whether the actor's purpose to engage in criminal conduct was sufficiently firm to warrant an inference that he might consummate the offense if left to his own devices. This is the view that garnered much support in AngloAmerican jurisdictions during the second half of the twentieth century. And it explains why common law courts have largely refused to water down the subjective culpability requirements while simultaneously broadening the scope of the objective elements of attempts. In contrast, if attempt liability is viewed as a vehicle for punishing those who place people in danger, the focus shifts from subjective culpability to whether the actor's conduct actually endangered the victim. According to this view, whether the actor was firmly set on completing a criminal offense is not the central feature of attempt liability. What is determinative is whether the conduct came sufficiently close to completion as to create a real risk of harm. This explains why civil law courts and commentators are loath to water down the objective elements of attempts, while they are generally willing to punish attempts even when the actor's purpose is not to commit an offense.

\section{Mens ReA - RecKlessness vs. Dolus Eventualis}

In European Continental jurisdictions, the most watered down form of intentional conduct is "dolus eventualis". In order for a defendant to act with dolus eventualis he must be aware that his conduct creates an unjustifiable risk of harm. In addition to awareness, however, acting with dolus eventualis has traditionally required a certain kind of attitude with regard to the risk created. There is no consensus regarding the kind of attitude that is relevant. For some, the actor must convince himself that he would act even if the consequence of the act is producing the proscribed harm. ${ }^{38}$ The actor thus "accepts" the causation of harm as a possible outcome and acts in spite of such awareness. For others, what matters is indifference rather than acceptance. According to this view, a defendant acts with dolus eventualis if he is aware that his conduct creates an unjustifiable risk of harm and he is indifferent as to whether the harm takes place. ${ }^{39}$

In contrast, a defendant who is aware that his conduct creates a risk of harm but is not indifferent to it acts with what continental scholars call conscious negligence. In such cases the defendant actually believes that the harm will not transpire because he trusts that he will be able to prevent it by making use of special skills or knowledge. ${ }^{40}$ Therefore, the difference between a defendant who acts with dolus eventualis and one who acts with conscious negligence is not whether they are aware of the risks created by their conduct. The difference lies in the attitude that the defendant adopts towards the risk that he creates. In cases of dolus eventualis, the actor

\footnotetext{
${ }^{38}$ This is the theory of "acceptance" or "acquiescence" to the harm. See Luzón Peña (n 15), 246.

${ }^{39}$ Ibid., 250.

${ }^{40}$ Ibid., 306.
} 
is not confident that he will be able to prevent the harm from taking place and he does not care whether it materializes or not. On the other hand, in cases of conscious negligence the defendant is confident that he will be able to prevent the harm that is risked by his conduct.

Differentiating dolus eventualis from conscious negligence is essential to discriminating between intentional and negligent conduct in civil law countries, for dolus eventualis is considered the most watered down form of intent, whereas conscious negligence is considered a type of negligence. Consequently, the difference between acting with dolus eventualis or conscious negligence is of significant practical import. This is because in continental jurisdictions negligent conduct usually remains unpunished. Furthermore, when negligent wrongdoing is criminalized, it is typically punished significantly less than intentional wrongdoing.

Although the distinction between dolus eventualis and conscious negligence is central to the way in which civil law jurisdictions approach the mens rea of offenses, the distinction never found its way into common law countries. The mental state known as recklessness is probably the closest Anglo-American analogue. According to the Model Penal Code, a defendant acts recklessly if he is aware that his conduct creates a substantial and unjustifiable risk of harm. ${ }^{41}$ Recklessness is a central concept in Anglo-American criminal law, for it defines the limits between advertent and inadvertent wrongdoing. The distinction is important, given that inadvertent wrongdoing is seldom punished in common law jurisdictions. ${ }^{42}$ Moreover, in the few instances in which inadvertent wrongdoing is punished it is usually punished much less severely than advertent wrongdoing.

The difference between recklessness and the continental mental states of dolus eventualis and conscious negligence is that a defendant acts recklessly as long as he is aware that his conduct creates an unjustifiable risk of harm, regardless of whether he is indifferent to the harm or trusts that he will be able to prevent it by employing special skills. In contrast, whether a defendant acts with dolus eventualis or conscious negligence ultimately hinges on whether he is indifferent to the harm or whether he trusts that he will be able to prevent it. As a result, the Anglo-American mental state of recklessness encompasses both dolus eventualis and conscious negligence.

The following table illustrates the differences between the continental mental states of dolus eventualis and conscious negligence and the common law mental state of recklessness:

\footnotetext{
${ }^{41}$ Model Penal Code Section 2.02.

${ }^{42}$ In Anglo-American jurisdictions, inadvertent wrongdoing is synonymous with negligent wrongdoing. The punishment of negligent (inadvertent) wrongdoing has always been the exception in common law jurisdictions. The phrase "inadvertent wrongdoing" is used instead of the more common "negligent wrongdoing" in order to avoid confusion with the European Continental way of conceptualizing criminal negligence. In civil law jurisdictions, criminal negligence has traditionally encompassed both "conscious negligence" and "unconscious negligence". Therefore, although the distinction between intentional and negligent wrongdoing is of central importance in both common and civil law countries, the distinction does not necessarily mean the same thing in both legal systems. In Anglo-American jurisdictions, the intent/negligence distinction tracks the difference between advertent (intent) and inadvertent (negligence) risk creation. On the other hand, in continental jurisdictions, the intent/negligence distinction does not track the difference between advertent and inadvertent risk creation, for advertent risk creation is an element of both a certain type of intent (dolus eventualis) and a certain type of negligence (conscious negligence).
} 


\begin{tabular}{|c|c|c|c|}
\hline Mental State & $\begin{array}{c}\text { Awareness of } \\
\text { Risk Created }\end{array}$ & $\begin{array}{c}\text { Indifference } \\
\text { towards harm } \\
\text { taking place }\end{array}$ & $\begin{array}{c}\text { Trust in } \\
\text { ability to } \\
\text { prevent harm } \\
\text { from } \\
\text { materializing }\end{array}$ \\
\hline Recklessness & Yes & Irrelevant & Irrelevant \\
\hline $\begin{array}{c}\text { Dolus } \\
\text { Eventualis }\end{array}$ & Yes & Yes & No \\
\hline $\begin{array}{c}\text { Conscious } \\
\text { Negligence }\end{array}$ & Yes & No & Yes \\
\hline
\end{tabular}

In light of the differences between these mental states, certain cases may generate significantly different criminal liability depending on whether they are approached from the civil law or the common law perspective. Take, for example, the facts that gave rise to the Puerto Rican case of Pueblo v. Colón Soto. ${ }^{43}$ Two friends were having drinks at a local bar. After a couple of cocktails, the defendant suggested that he could shoot his friend's hat off with a single gunshot. The friend agreed to stand motionless and allow the defendant to shoot. The defendant's shot missed the hat, but reached the friend's head, killing him. Defendant was charged with intentional homicide. Defense counsel argued, however, that he should be convicted of negligent homicide.

The Puerto Rican Supreme Court concluded that the defendant could be held liable for intentional homicide because attempting to shoot a baseball cap from someone's head is an act that is rife with danger. From this, the fact finder could reasonably infer that the defendant was aware that his act created an unjustifiable risk of death. This is the way the case would usually by approached in Anglo-American jurisdictions. The defendant acted recklessly because he was aware that his act unreasonably endangered another person's life. Consequently, defendant could be held liable for advertent wrongdoing, which is punished significantly more than inadvertent wrongdoing.

The case might very well be decided differently in continental jurisdictions, given that awareness of the risk created by the conduct is not enough to trigger the more significant liability that attaches for acting with dolus eventualis. In addition, the actor must be indifferent as to whether the harm ensues. Although it is unclear whether the defendant in Colón Soto was indifferent to his friend's death, there are a couple of facts that suggest that he was not. First, the defendant seemed fairly confident in his ability to shoot his friend's hat off without causing him physical harm. Second, people are generally not indifferent to whether they kill their friends. As a result, the evidence probably supports an inference that the defendant trusted that he would not kill his friend. This suggests that it could plausibly be argued that the defendant acted with conscious negligence rather than dolus eventualis. If so, defendant could be convicted of negligent homicide, even if the court is convinced that he was aware that his conduct created an unjustifiable risk of death. Convicting a defendant in circumstances such as these of negligent

${ }^{43}$ Pueblo v. Colón Soto, 109 D.P.R. 545 (1980). 
homicide would be difficult to imagine in Anglo-America. At the very least, such conduct would be punished as reckless homicide, if not murder. ${ }^{44}$

Interestingly, it seems that in recent years the distinction between dolus eventualis and conscious negligence is increasingly being called into question. The charge is led mostly by the continental courts and scholars that defend the so called "probability theory" of dolus eventualis. According to the this theory, a defendant acts with dolus eventualis when he accurately perceives the danger created by his conduct and acts in spite of having such awareness. ${ }^{45}$ In contrast, a defendant acts with conscious negligence when he fails to correctly assess the danger created by his conduct. In its most extreme version, the theory leads to a finding of intent whenever the actor is aware that his conduct creates an unreasonable risk of harm. Many scholars throughout the civil law realm have endorsed a version of this theory of dolus eventualis. ${ }^{46}$ Some courts are starting to follow suit. ${ }^{47}$

If this trend continues, the differences between the civil law mental state of dolus eventualis and the common law mental state of recklessness will become less meaningful. This is perhaps one of the instances in which what has traditionally been considered a point of divergence between Anglo-American and continental law criminal may ultimately end up being a point of convergence. Somewhat surprisingly, if this were to happen it will mostly be the consequence of continental scholars and courts abandoning or rethinking the traditional approach to dolus eventualis rather than Anglo-American courts and scholars supplementing recklessness with additional mental states such as "acceptance" or "indifference".

The reasons underlying this rethinking of dolus eventualis in continental jurisdictions are fairly evident. First, it is unclear whether the actor who is aware that his conduct creates a risk of harm but is indifferent towards whether it takes place is significantly more worthy of blame than the actor who is similarly aware of the risk but trusts that he will be able to prevent it. Why should the law favor those who consciously engage in risky undertakings while foolishly believing that harm will not result? Second, it will often be very difficult to prove whether someone was aware of a risk but indifferent to it or whether he was aware but thought that he could prevent it. Requiring prosecutors to prove indifference/acceptance in addition to awareness imposes a probative burden in circumstances in which it is unclear whether the benefits of doing so outweigh the evidentiary costs that requiring such proof creates. This problem is compounded in jurisdictions that have jury trials. If the distinction between dolus eventualis and conscious negligence has baffled judges and scholars for decades, it is difficult to imagine how much added confusion it would sow in the minds of juries.

It is thus not surprising that support for the traditional way of distinguishing between dolus eventualis and conscious negligence is waning in continental jurisdictions. What is

\footnotetext{
${ }^{44}$ Reckless homicide is the most watered down kind of advertent homicide punished in Anglo-American jurisdictions. Reckless homicide requires that the actor be aware that his conduct creates an unjustifiable risk of death. In contrast, murder sometimes requires that the actor's conduct reveal "gross indifference to the value of human life". It is unclear whether the gross indifference requirement is a mental state in addition to awareness of the risk or if it is a way of objectively distinguishing between risks that are grossly blameworthy and risks that are less blameworthy.

${ }^{45}$ See, e.g., Mir Puig (n 19), 267-268.

${ }^{46}$ In Spain, see, e.g., Mir Puig, Ibid. In Germany, see, Jakobs (n 14), 329-330.

${ }^{47}$ Spanish courts, for example, seem to be slowly moving in this direction. See Mir Puig, Ibid., 278, fn 75.
} 
surprising, however, is that this erosion of support has gone relatively unnoticed in AngloAmerica, especially given that the trend in civil law countries seems to be to move towards something more akin to the common law mental state of recklessness. In fact, the continental experience with dolus eventualis is sometimes cited in Anglo-America as proof that adding "acceptance" or a functionally equivalent mental element to recklessness is a sensible and workable proposition. ${ }^{48}$ The history of dolus eventualis suggests otherwise. Civil law courts and scholars have struggled so mightily with dolus eventualis that many are now slowly redefining it in a way that eliminates reference to "acceptance" or similar mental states. It is thus problematic to propose that Anglo-America move in the direction of dolus eventualis when those who have embraced it for so many decades are beginning to move away from it.

\section{CONCLUSION}

There is much use to approaching criminal law from a comparative perspective. The relevance of comparative criminal law to international criminal law is obvious. While less evident, engaging in comparative analysis may also be relevant in the domestic context. A lot can be learned from understanding how foreign legal systems have tackled important issues of criminal theory. Doing so may help local actors identify criminal law doctrines that are in need of change. It may also aid domestic courts in construing constitutional provisions related to substantive criminal law. Although the benefits of engaging in such comparative analysis may be considerable, it is important to proceed cautiously when comparing the criminal laws of different jurisdictions. Language barriers make access to foreign sources of criminal law difficult. Additionally, the content and scope of the criminal laws of a foreign jurisdiction cannot be fully comprehended without taking into account the historical and cultural contingencies that helped shape such laws. Nevertheless, expending the effort that is necessary to overcome these obstacles is worth it. As this Chapter's discussion of dolus eventualis and recklessness illustrates, comparative analysis allows rethink current approaches to criminal law in light of the experiences that others have had dealing with similar problems. Furthermore, as this Chapter's brief comparative survey of attempt liability reveals, comparative criminal law offers an opportunity to better understand why domestic criminal law takes its current shape.

\section{BIBLIOGRAPHY}

Luis E. Chiesa, Substantive Criminal Law: Cases, Comments and Comparative Materials (forthcoming 2014)

Mirjan R. Damaska, The Faces of Justice and State Authority: A Comparative Approach to the Legal Process (1986)

Markus D. Dubber, 'Comparative Criminal Law', in M. Reimann and R. Zimmerman (eds), The Oxford Handbook of Comparative Law (2006)

Markus D. Dubber and Kevin J. Heller (eds), Handbook of Comparative Criminal Law (2011)

Albin Eser, George P. Fletcher, and Karin Cornils (eds), Justification and Excuse: Comparative Perspectives (1987)

George P. Fletcher, Rethinking Criminal Law (1978)

George P. Fletcher, Basic Concepts of Criminal Law (1998)

\footnotetext{
${ }^{48}$ See, e.g., Alan C. Michaels, 'Acceptance: The Missing Mental State', (1998) 71 Southern California L.R. 953.
} 
Hernán Gullco and Edmundo Hendler, Casos de Derecho Penal Comparado (2003)

Alan Reed and Michael Bohlander (eds), Participation in Crime: Domestic and Comparative Perspectives (2013)

Alan Reed and Michael Bohlander (eds), Loss of Control and Diminished Responsibility: Domestic, Comparative and International Perspectives (2013)

Alan Reed and Michael Bohlander (eds), General Defences: Domestic and Comparative Perspectives (forthcoming 2014)

Thomas Weigend, 'Criminal Law and Criminal Procedure', in Jan M. Smits (ed.), Elgar Encyclopedia of Comparative Law (2012)

James Q. Whitman, Harsh Justice: Criminal Punishment and the Widening Divide Between America and Europe (2003) 